\title{
Genetic variations among and within the populations of Calabrian pine (Pinus brutia Ten.) in Turkey
}

\author{
Osman TOPACOĞLU ${ }^{1 *}$, Hakan ŞEVIK ${ }^{2}$, Ahmet SIVACIOĞLU1 $^{1}$, Ferhat KARA $^{1}$ \\ ${ }^{1}$ Kastamonu University, Faculty of Forestry, Department of Forest Engineering, Kastamonu, 37100, \\ Turkey. \\ 2 Kastamonu University, Faculty of Engineering and Architecture, Kastamonu, 37100, Turkey. \\ *Corresponding author:otopacoglu@kastamonu.edu.tr
}

Received Date: 08.08.2017

Accepted Date: 07.11.2017

\begin{abstract}
Aim of study: Generic variety is an important criterion for the sustainability of economically important tree species. The aim of this study was to determine the differences among registered seed stands of Calabrian pine (Pinus brutia Ten.) based on some morphological traits in Turkey

Material and Methods: For this purpose, seed samples from 14 registered seed stands dominated by the species were obtained from the Forest Tree Seed and Tree Breeding Research Directorate of Turkey. Thirteen morphological traits of the seedlings including the germination percentage, survival rate, survival rate/germination percentage ratio, root-collar diameter (when seedlings were 40-45 days old), hypocotyl length, cotyledon number, cotyledon length, cotyledon width, root-collar diameter (when seedlings were 1-year old), epicotyl length, needle length, needle width, and branch number were monitored.
\end{abstract}

Main results: The obtained data was analyzed using the Cluster and Penrose analysis. The Cluster and Penrose analysis showed that there were significant differences among and within the Pinus brutia seed stands in terms of the morphologic characteristics. Genetic variances among the populations were much lower than those within the populations.

Research highlights: The study suggested that high genetic variation within the population may be an occasion for the genetic improvement in breeding programs.

Keywords: Calabrian pine, Genetic variation, Heritability, Morphological traits, Seed stands

\section{Türkiye'deki Kızılçam (Pinus brutia Ten.) populasyonları arasında ve içindeki genetik varyasyon}

\section{Özet}

Çalışmanın amacı: Genetik varyasyon, ekonomik açıdan değerli ağaç türlerinin sürdürülebilirliği için önemli bir kriterdir. Bu çalışmada, Türkiye'deki Kızılçam (Pinus brutia Ten.) tohum meşcerelerinde türün bazı morfolojik özellikleri kullanılarak genetik farklılıkların belirlenmesi amaçlanmıştır.

Materyal ve Yöntem: Bunun için; tohum örnekleri Orman Ağaçları ve Tohumları Islah Araştırma Entitüsü Müdürlüğünde kayıtlı 14 adet kızılçam tohum meşcerelerinden elde edilen tohumlar ile gerçekleştirilmiştir. Fideciklerden elde edilen13 morfolojik özellikte ( çimlenme yüzdesi, yaşama yüzdesi, yaşama yüzdesi/ çimlenme oranı, kök boğazı çap1 (40-45 günlük fideciklerde), hipokotil uzunluğu, kotiledon sayısı ,kotilodon uzunluğu, kotilodon genişliği, kök boğazı çapı (1 - yaşlı fideciklerde), epikotil uzunluğu, ibre uzunluğu, ibre genişliği ve dal sayısı) ölçüm yapılmıştır.

Sonuçlar: Elde edilen veriler Cluster ve Penrose istatistiki analizlerle test edilmiştir. Analizlerde Kızılçam tohum meşcerelerinde ve meşcere arasında morfolojik özellikler bakımından önemli farklılıkların bulunduğu görülmektedir. Genetik farklılıkların populasyonlar arasında, populasyonlar içindeki farklılıklardan daha az olduğu tespit edilmiştir.

Araştırma vurguları: $\mathrm{Bu}$ çalışma populasyonlar içindeki yüksek genetik varyasyonun islah programlarında genetik kazanç için bir firsat olabileceğini göstermektedir.

Anahtar Kelimeler: Kızılçam, Genetik varyasyon, Heridabilite, Morfolojik karakterler, Tohum meşceresi. 


\section{Introduction}

Calabrian pine (Pinus brutia Ten.) can be found throughout the eastern Mediterranean (Panetsos, 1981). It has a distribution area of 5.4 million ha occupying mostly the forest lands in the southern and western parts of Turkey (Anonymous, 2014). The natural range of this species mostly includes the areas from the sea level up to $1200 \mathrm{~m}$ of elevation, and it can occasionally be seen at higher elevations up to $1400 \mathrm{~m}$ in the Taurus Mountains along the Mediterranean Coast (Gülcü \& Çelik, 2009). Calabrian pine is also economically valuable (Boydak, 2004) since this species is one of the fastest growing species of Turkey with a mean increment of $10.52 \mathrm{~m} 3$ ha-1 year-1 (Erkan, 1996). Thus, it is usually considered as a potential species for common and industrial plantations, and selected as the target species in the "Activity Plan of Industrial Plantations for the 20132023 period in Turkey" (Anon, 2013). In addition, due to its drought resistance, Calabrian pine plays a vital role in erosion control practices in Turkey (Gülcür et al., 1993). Although a majority of the Calabrian pine forests located in the Mediterranean region is either under the threat of or exposed to forest fires (Küçük et al., 2008), the species has the ability to re-occupy the burned areas following the fires.

Even though Calabrian pine has a large natural distribution area in Turkey, due to frequent wildfires, changes in land use and excessive grazing, the distribution area of the species has been narrowed (Işık \& Kaya, 1997). Thus, there has been an increasing interest in the afforestation activities within the natural distribution area of the species. In addition, Calabrian pine has been commonly preferred in the afforestation activities elsewhere because of its fast growing ability and resistance to drought. However, these activities necessitate the supply of high quality seeds from the registered sources such as seed stands and clonal seed orchards because it is possible that human-made disturbances including wildfires, land use change and grazing negatively affected the genetic diversity of Calabrian pine populations (Işık \& Kaya, 1997). As of today, 77 natural Calabrian pine stands (occupying 11757 ha) have been registered as seed collecting stands for nurseries in Turkey (Anon, 2016).

Genetic variety is the fundamental source of all biological diversity. It provides the raw material necessary for adaptation. Millar (1999) pointed out that without genetic variation, it would not be possible for species to adapt to changing environments. Due to the adaptation ability of forest tree species following the environmental or human-made disturbances, forest ecosystems need genetic variation for maintenance and long term stability. Genetic variations are considered to be the essential parameters of the long term sustainability of forest ecosystems (MullerStarck et al., 1992; Yücedağ \& Gailing 2013), especially for the degraded ecosystems such as Calabrian pine that exposed to frequent human-made disturbances. It is certain that further information on the adaptive significance of genetic variation may be the key for the successful afforestation activities in Turkey (Işık \& Kaya, 1997).

Because of the wide distribution of Calabrian pine, observation of various morphological traits in terms of regional adaptations seems to be essential (Kurt et al., 2011). However, to our knowledge, neither the genetic variation of Calabrian pine to allocate the seed sources to the proper planting sites, nor the genetic parameters for the purpose of tree breeding have been welldocumented (Gülcü \& Üçler, 2008). Morphological traits and isoenzymes analysis, have been some of the most widely used methods for assessing the genetic variation of some pine (Pinus spp.) species (Glowacki \& Stephan, 1994; Turna, 2003; Bilgen \& Kaya, 2007; Romero et al., 2006; Sivacioğlu et al., 2009; Sivacioğlu \& Ayan, 2010; Sivacioğlu, 2010; Şevik et al., 2010; Şevik, 2012; Şevik et al., 2012; Topacoglu, 2013). In this study, it was aimed to determine the rate of variations among and within populations on genetic diversity using the morphological traits in Calabrian pine species. Specific objectives were to determine the genetic distance among the populations, and the heritability value of the morphological traits. It is hypothesized that there could be genetic variations among and within Calabrian pine populations, which 
could have important implications for afforestation practices.

\section{Material and Method}

Due to vast natural distribution of Calabrian pine within the Mediterranean region, the material seed stands were selected in that area (Figure 1).

Calabrian pine is known to be a shadeintolerant species, and it usually occupies lands at higher elevations on southern slopes than northern. In regard to soil demand, this species can grow in soils that are low in organic matter and relatively infertile. Within the natural range of Calabrian pine, soils are mostly sedimentary, volcanic and metamorphic bed rocks (Boydak et al., 2006; Neyişçi 1987).

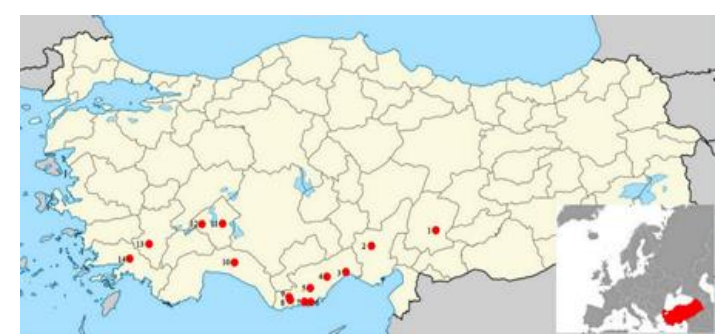

Figure 1. Location of sampled seed stands.

Seed samples were obtained from the Forest Tree Seed and Tree Breeding Research Directorate of Turkey. The samples were collected from 14 registered seed stands within the natural range of Calabrian pine in Turkey (Table 1).

Table 1. Location and some of the ecological conditions of 14 Pinus brutia populations from Turkey

\begin{tabular}{lllll}
\hline Pop. No & Region & District & Unit & Altitude(m) \\
\hline 1 & Muğla & Marmaris & Çetibeli & 60 \\
2 & Mersin & Silifke & Yeşilovacık & 100 \\
3 & Mersin & Bozyazı & Tekmen & 250 \\
4 & Isparta & Bucak & Melli & 350 \\
5 & K.Maraş & Antakya & Uluçınar & 385 \\
6 & Mersin & Anamur & Gökçesu & 500 \\
7 & Mersin & Bozyazi & Toldağ & 500 \\
8 & Mersin & Gülnar & Pembecik & 650 \\
9 & Antalya & Gündoğmuş & Guzelbağ & 650 \\
10 & Isparta & Sütçüler & Karadağ & 650 \\
11 & Adana & Pos & Soğukoluk & 735 \\
12 & Denizli & Acrpayam & Kelekçi & 850 \\
13 & Mersin & Erdemli & Tömük & 900 \\
14 & Mersin & Anamur & Çaltıbükü & 925 \\
\hline
\end{tabular}

In early March of 2014, the seeds were sown using the conventional methods in a nursery at an altitude of $850 \mathrm{~m}$, in Kastamonu City. For each seed stand, 30 seeds were sown in a growing media, and this was replicated 4 times (i.e. 120 seeds in total for each seed stand). The growing media consisted of river sand, forest soil and peat in a proportion of $1: 1: 2$, respectively, and covered with perlite.

The measurements were taken twice during the study; the first was when the seedlings were 40-45 days old while the second one was when the seedlings were 1year old. During the first measurements, 6 parameters including the germination percentage (GP), root-collar diameter
(RCD1-mm), hypocotyl length (HL-mm), cotyledon number $(\mathrm{CN})$, cotyledon length (CL-mm) and cotyledon width (CW-mm) of the seedlings were measured for each stand after 40-45 days following the sowing. Following the first vegetation period, when seedlings were 1-year old, 7 parameters including the survival rate (SR), SR/GP ratio, root-collar diameter (RCD2-mm), epicotyl length (EL-mm), needle length (NL-mm) and needle width (NW-mm), and branch number (BN) of the seedlings were measured for each stand.

Differences among the populations were examined using the analysis of variance (ANOVA). Duncan Test was used for multiple comparisons of populations. 
Hierarchical Cluster Analysis was used to measure the distances between the populations. Relationships among the 13 morphologic traits were tested using the correlation analyses (Işı1k \& Kaya, 1997). In addition, in order to present the differences mathematically among the populations, the data were analyzed using the Penrose analysis (Formulas 1 and 2). Data were standardized before the calculations and the morphological distance among seed stands were estimated. Analyses of traits were based on the population means. The tests were conducted using the SPSS 18.0 Statistical Program (IBM SPSS Statistics, 2009).

$$
Z_{i, k}=\frac{\left(x_{i, k}-\bar{x}_{k}\right)^{2}}{S_{k}} \quad \text { (Formula 1) }
$$

where $\mathrm{Zi}, \mathrm{k}$ refers to standardized values of the kth characteristics of the ith population while Xi,k stands for mean of the kth characteristics of the ith populations for the kth characteristics, and Sk refers to the standard deviation of the populations for the kth characteristics (Şevik et al., 2010).

$D_{i, j}=\sum_{k=1}^{n} \frac{\left(\mu_{k i}-\mu_{k j}\right)^{2}}{p \cdot V_{k}} \quad($ Formula 2$)$

where Dtj refers to the morphological distance between the ith population and the jth populations, while $\mathrm{n}, \mu \mathrm{kj}$ and $\mathrm{Vk}$ are the number of characteristics, the standardized values of the kth characteristics of the jth population, and the variance of standardized averages of the kth characteristics (Şevik et al., 2010), respectively. Analysis was applied by standardized values in SPSS statistical package program.

In addition, in order to estimate the variance components of morphological characters within and among the seed stands, the Residual (or Restricted) Maximum Likelihood (REML) method was conducted using the PROC VARCOMP function in the Statistical Analysis Software (SAS Institute, 1987). Estimator of REML method was obtained by solving the same set of Formulas used for the Minimum Variance Quadratic Unbiased Estimation (MIVQUE) which also estimates the variance components (Rao, 1971; Swallow \& Monahan, 1984).
The difference between the REML and MIVQUE methods is that the solution is an iterative for REML method (Swallow \& Monahan, 1984). REML has its own model which generates variance component estimates.

$y i j=\mu+\alpha i+\beta j(i)+e i j(i=1, \ldots, a j=1, \ldots, b k=1, \ldots, n)$

where yij is the estimation of morphological characters on the jth tree of the ith population, $\mu$ is unknown constant, $\alpha$ i is the level of ith tree, $\beta i(j)$ is the level of the ith tree of the jth population, eij is the error term associated with the ith tree of the jth population.

Heritability values (H2) based on the seed stand were estimated as the ratio of total genetic variance $(\sigma 2 \mathrm{C})$ to total phenotypic variance $(\sigma 2 \mathrm{C}+\sigma 2 \mathrm{E})$ where $\sigma 2 \mathrm{E}$ was the within population mean square and $\sigma 2 \mathrm{C}$ was the among population mean square within population mean square (Matziris, 1984).

\section{Results}

The ANOVA analysis showed that there were significant differences among the seed stands (populations) in terms of GP ( $p>0.05)$, SR ( $p>0.05), B N(p>0.05), C L(p>0.01)$, RCD2 (p>0.01), EL ( $>0.01)$, CN ( $>0.001)$, $\mathrm{CW}(\mathrm{p}>0.001)$ and NW $(\mathrm{p}>0.001)$ (Table 2). However, the seed source (populations) had no effects on SR/GP ratio, RCD1, HL and NL (Table 2). The lowest GP (42.5\%) and SR $(40 \%)$ values were determined in the Population-11 whereas the highest GP $(67.5 \%)$ and SR $(65 \%)$ were determined for the Population-5 (Table 2). In addition, the highest $\mathrm{CN}(9.4 \mathrm{~mm}), \mathrm{CL}(29.27 \mathrm{~mm})$ and CW $(0.98 \mathrm{~mm})$ were determined within the Population-5 (Table 2). Moreover, although not the highest, Population-5 presented relatively higher RCD2 (1.92 mm), EL (50.77 mm), NL (20.98 mm), NW (0.66 mm) and $\mathrm{BN}$ (3.6) across all populations (Table 2 ). The smallest RCD growth at the end of the growing season (RCD2) was monitored in Population-9. Across the all populations, Population-13 had the smallest CN (8.1) and $\mathrm{CW}(0.78 \mathrm{~mm})$, and relatively smaller GP (0.46\%), SR (44\%), CL (26.28 mm), RCD2 $(1.75 \mathrm{~mm})$ (Table 2). 
Table 2. Mean values and comparisons of studied morphological traits.

\begin{tabular}{|c|c|c|c|c|c|c|c|c|c|c|c|c|c|}
\hline $\mathrm{P}$ & GP & SR & SR/GP & RCD1 & $\mathrm{HL}$ & $\mathrm{CN}$ & CL & $\mathrm{CW}$ & RCD2 & EL & NL & NW & $\mathrm{N}$ \\
\hline 1 & $50 \mathrm{abc}$ & $475 \mathrm{abc}$ & 95,63 & 1,16 & 18,7 & $8,4 a b c$ & $2367 a$ & $0,78 \mathrm{ab}$ & $169 \mathrm{ab}$ & $36,07 \mathrm{ab}$ & 18.33 & $0,73 \mathrm{c}$ & $325 \mathrm{ab}$ \\
\hline 2 & $5875 \mathrm{abc}$ & $56.25 \mathrm{abc}$ & 96,35 & 1,11 & 20,96 & $8,9 \mathrm{bcd}$ & $2806 \mathrm{~cd}$ & $0,91 \mathrm{de}$ & $176 \mathrm{bc}$ & $40,53 \mathrm{abc}$ & 20.49 & $0,57 \mathrm{a}$ & $363 \mathrm{bc}$ \\
\hline 3 & $63,75 b c$ & $62,5 b c$ & 96,67 & 1,15 & 21,82 & 8,9abcd & $29,52 \mathrm{~d}$ & $0,88 \mathrm{bcde}$ & $1,98 \mathrm{c}$ & $54,09 \mathrm{~d}$ & 21,06 & $0,61 \mathrm{ab}$ & $4.6 c$ \\
\hline 4 & $65 \mathrm{bc}$ & $57,5 \mathrm{abc}$ & 86,25 & 1,14 & 21,05 & $9,4 \mathrm{~d}$ & $27,5 \mathrm{bcd}$ & $0,86 \mathrm{abcd}$ & $1,82 \mathrm{bc}$ & $45,65 \mathrm{bcd}$ & 20,37 & $0,6 \mathrm{ab}$ & $3,81 \mathrm{bc}$ \\
\hline 5 & $67,5 \mathrm{c}$ & $65 \mathrm{c}$ & 97,5 & 1,17 & 23,26 & $9,4 \mathrm{~d}$ & $29,27 d$ & $0,98 \mathrm{e}$ & $1,92 \mathrm{bc}$ & $50,77 \mathrm{~cd}$ & 20,98 & $0,66 a b c$ & $3,6 \mathrm{bc}$ \\
\hline 6 & $51,25 a b c$ & $45 \mathrm{abc}$ & 91,11 & 1,11 & 21,14 & $9,1 \mathrm{~cd}$ & $27,36 \mathrm{bcd}$ & $0,87 \mathrm{abcd}$ & $1,86 \mathrm{bc}$ & 43,16abcd & 19,64 & $0,6 a b$ & $3,47 a b c$ \\
\hline 7 & $50 \mathrm{abc}$ & $45 \mathrm{abc}$ & 85,56 & 1,1 & 20,83 & $8,2 \mathrm{ab}$ & 25,99abcd & $0,79 a b c$ & $1,93 \mathrm{c}$ & $51,28 \mathrm{~cd}$ & 20,95 & $0,7 \mathrm{c}$ & $4,15 \mathrm{bc}$ \\
\hline 8 & $48,75 \mathrm{abc}$ & $47,5 \mathrm{abc}$ & 98,44 & 1,17 & 20,62 & $9,4 \mathrm{~d}$ & 26,87abcd & $0,81 \mathrm{abcd}$ & $1,86 \mathrm{bc}$ & $41,05 \mathrm{abc}$ & 19,73 & $0,72 \mathrm{c}$ & $3,44 a b c$ \\
\hline 9 & $56,25 \mathrm{abc}$ & $53,75 \mathrm{abc}$ & 95 & 1,15 & 20,03 & $8,2 \mathrm{ab}$ & $24,53 \mathrm{ab}$ & $0,82 \mathrm{abcd}$ & $1,54 \mathrm{a}$ & $35,69 \mathrm{ab}$ & 19,57 & $0,72 \mathrm{c}$ & $2,2 \mathrm{a}$ \\
\hline 10 & $61,25 \mathrm{abc}$ & $56,25 \mathrm{abc}$ & 91,98 & 1,13 & 22,63 & $8,8 \mathrm{abcd}$ & $28,33 \mathrm{~cd}$ & $0,81 \mathrm{abcd}$ & $1,8 \mathrm{bc}$ & 43,91abcd & 20 & $0,69 \mathrm{bc}$ & $3,13 \mathrm{ab}$ \\
\hline 11 & $42,5 \mathrm{a}$ & $40 \mathrm{a}$ & 92,86 & 1,13 & 22,61 & $8,7 \mathrm{abcd}$ & $26,43 \mathrm{abcd}$ & 0,89 cde & $1,84 \mathrm{bc}$ & $40,5 \mathrm{abc}$ & 20,1 & $0,59 a$ & $3,27 \mathrm{ab}$ \\
\hline 12 & $62,5 \mathrm{bc}$ & $61,25 b c$ & 98,75 & 1,17 & 19,48 & $8,4 a b c$ & $25,09 \mathrm{abc}$ & $0,81 \mathrm{abcd}$ & $1,85 \mathrm{bc}$ & $33,14 \mathrm{a}$ & 17,39 & $0,73 \mathrm{c}$ & $3,57 \mathrm{bc}$ \\
\hline 13 & $46,25 \mathrm{ab}$ & $43,75 \mathrm{ab}$ & 93,33 & 1,01 & 20,75 & $8,1 \mathrm{a}$ & $26,28 \mathrm{abcd}$ & $0,78 \mathrm{a}$ & $1,75 a b c$ & 44,93abcd & 21,02 & $0,64 a b c$ & $3 a b$ \\
\hline 14 & $57,5 \mathrm{abc}$ & $53,75 \mathrm{abc}$ & 95,36 & 1,12 & 21,84 & $8,5 \mathrm{abc}$ & $28,49 \mathrm{~cd}$ & $0,82 \mathrm{abcd}$ & $1,82 \mathrm{bc}$ & $41,64 \mathrm{abc}$ & 19,06 & $0,68 \mathrm{bc}$ & $4 \mathrm{bc}$ \\
\hline Average & 55,8 & 52,5 & 93,91 & 1,13 & 21,12 & 8,74 & 26,96 & 0,84 & 1,82 & 43,03 & 19,91 & 0,66 & 3,51 \\
\hline F Values & $1,82^{*}$ & $1,81^{*}$ & $1,25 \mathrm{~ns}$ & $0,89 \mathrm{~ns}$ & $1,6 \mathrm{~ns}$ & $3,33 * * *$ & $2,69 * *$ & $3,32 * * *$ & $2,33 * *$ & $2,72 * *$ & $1,63 \mathrm{~ns}$ & $3,91 * * *$ & $2,01^{*}$ \\
\hline Max. & 67,5 & 65 & 98,75 & 1,17 & 23,26 & 9,4 & 29,52 & 0,98 & 1,98 & 54,09 & 21,06 & 0,73 & 4,6 \\
\hline Min. & 42,5 & 40 & 85,56 & 1,01 & 18,7 & 8,1 & 23,67 & 0,78 & 1,54 & 33,14 & 17,39 & 0,57 & 2,2 \\
\hline Diff. (\%) & 58,82 & 62,5 & 15,42 & 15,84 & 24,39 & 16,05 & 24,71 & 25,64 & 28,57 & 63,22 & 21,1 & 28,07 & 109,09 \\
\hline
\end{tabular}


The results of Duncan test indicated that the Population-5 was included in the last homogeny groups for all traits, and the Population-3 was included in the last homogeny group for all characters except NW. Similarly, the Population-13 was in the first homogeny group for all traits (Table 2).

As a result of the Penrose analysis, the maximum values of 4.59 (Population-5 and Population-9), 4.1 (Population-9 and Population-11), and 3.63 (Population-5 and Population-14) were determined between the populations given in parenthesis (Table 3). The minimum values determined following the Penrose analysis were 0.34 (Population-6 and Population-8), 0.35 (Population-4 and Population-8) and 0.39 (Population-10 and Population-14) (Table 3). When morphological distances approach to zero, the similarity among the populations increases, thus, Population-8 and Population6, Population-8 and Population-4, and Population-10 and Population-14 presented similar characteristics across all populations.

On the cluster dendrogram constructed on the basis of Euclidean distances with the use of the nearest neighbor method for 13 quantitative morphological traits, two distinct groups could be noticed. The first group included the populations $2,14,10,9,12,4,3$ and 5 while the remaining populations were included in the second group. The first group can also be divided into two sub-groups in itself; the first sub-group included populations 3 and 5 while the second subgroup included the remainders. Thus, in fact, the results indicated that there were three distinct groups within the populations (Figure 2).

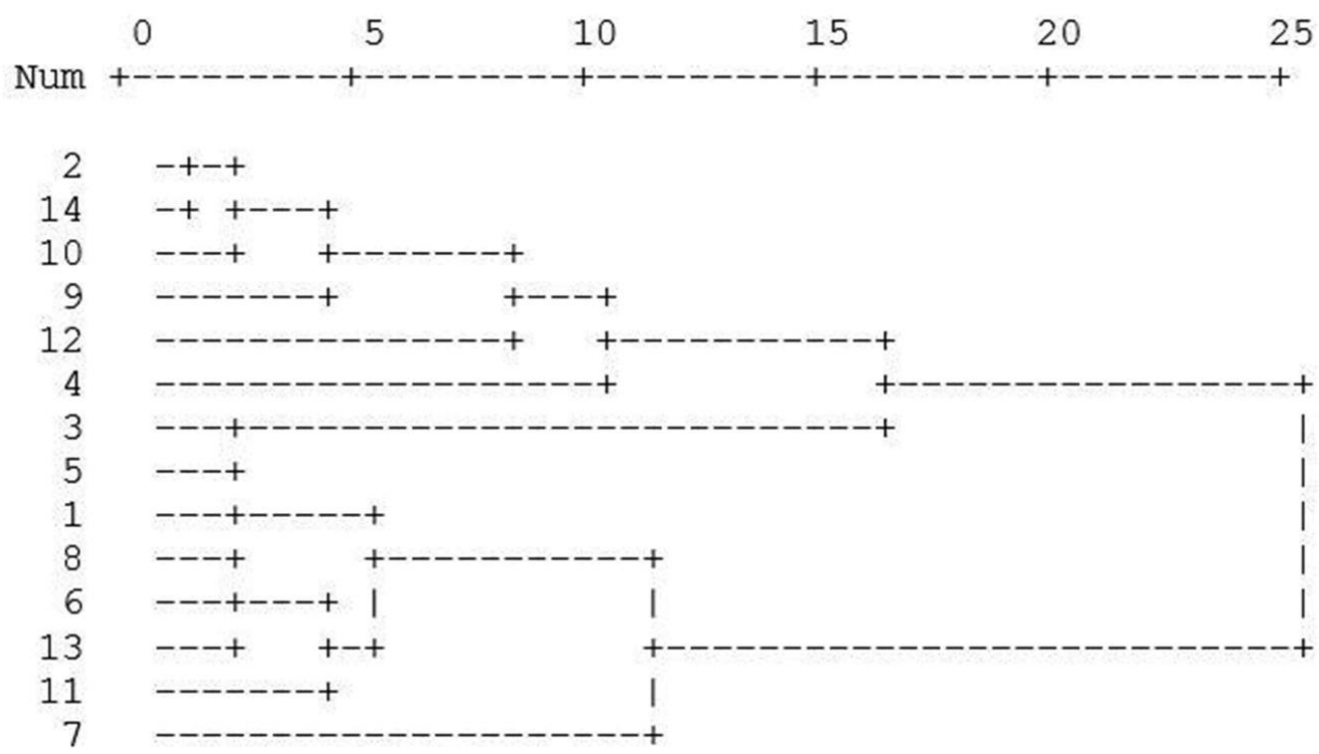

Figure 2. Dendrogram of 14 populations of Calabrian pine based on morphological traits.

Based on the Penrose values (Table 3) and the Cluster analysis (Figure 2) together with geographical proximity and genetical distance, remarkable variations were presented among the populations. Based on the Cluster analysis, Populations 2 and 14 were the closest ones in terms of genetic distance whereas these populations were furthest in terms of geographical proximities. On the other hand, Populations 8 and 9 were the closest by means of geographical proximities whereas these populations were the furthest by means of genetic distance.

Table 4 shows the correlation analyses that reflect the fact that positive significant correlation were observed among many traits. Maximum correlation values were between GP and SR (0.958), EL and BN (0.692), RCD2 and EL (0.672), RCD2 and BN (0.640). 
Table 3. Results of penrose method.

\begin{tabular}{llllllllllllll}
\hline $\mathrm{P}$ & 2 & 3 & 4 & 5 & 6 & 7 & 8 & 9 & 10 & 11 & 12 & 13 & 14 \\
\hline 1 & 1,57 & 1,22 & 2,72 & 2,00 & 2,25 & 1,95 & 2,26 & 1,86 & 1,64 & 2,22 & 0,89 & 2,69 & 1,80 \\
2 & & 1,94 & 1,37 & 3,53 & 0,49 & 1,55 & 0,93 & 2,36 & 1,01 & 1,54 & 1,85 & 2,43 & 1,07 \\
3 & & & 2,41 & 2,49 & 2,19 & 1,13 & 2,47 & 1,49 & 1,87 & 1,97 & 1,46 & 2,5 & 2,01 \\
4 & & & & 3,39 & 0,72 & 0,76 & 0,35 & 3,24 & 1,54 & 1,93 & 1,99 & 2,32 & 1,57 \\
5 & & & & & 3,35 & 2,24 & 2,96 & 4,59 & 3,1 & 2,73 & 2,44 & 2,24 & 3,63 \\
6 & & & & & & 1,32 & 0,34 & 2,77 & 0,8 & 1,19 & 2,05 & 1,77 & 0,89 \\
7 & & & & & & & 1 & 2,18 & 1,89 & 2,43 & 1,33 & 1,95 & 1,74 \\
8 & & & & & & & & 2,76 & 1,21 & 1,62 & 1,96 & 1,45 & 1,29 \\
9 & & & & & & & & & 2,37 & 4,1 & 3,39 & 3,52 & 2,05 \\
10 & & & & & & & & & 1,13 & 2,27 & 2,53 & 0,39 \\
11 & & & & & & & & & & 2,24 & 2,65 & 2,25 \\
12 & & & & & & & & & & & & 2,51 & 2,15 \\
13 & & & & & & & & & & & & 2,27 \\
\hline
\end{tabular}

Table 4. Results of correlation analysis

\begin{tabular}{|c|c|c|c|c|c|c|c|c|c|c|c|c|}
\hline GP & SR & SR/GP & RCD1 & $\mathrm{HL}$ & $\mathrm{CN}$ & CL & $\mathrm{CW}$ & RCD2 & EL & NL & NW & $\mathrm{BN}$ \\
\hline$\overline{\mathrm{GP}}$ & $0,948^{* * *}$ & 0,049 & 0,017 & $0,221^{* *}$ & 0,116 & $0,340^{* * *}$ & 0,123 & $0,141^{*}$ & $0,137^{*}$ & 0,090 & 0,015 & 0,126 \\
\hline SR & & $0,363^{* *}$ & 0,026 & $0,253^{* *}$ & $0,149^{*}$ & $0,409^{* *}$ & $0,189^{* *}$ & 0,125 & 0,102 & 0,061 & 0,026 & 0,093 \\
\hline $\mathrm{SR} / \mathrm{GP}$ & & & $0,141^{*}$ & $0,217^{* *}$ & $0,265^{* *}$ & $0,350^{* *}$ & $0,323^{* *}$ & 0,024 & $-0,038$ & $-0,045$ & 0,05 & $-0,011$ \\
\hline $\mathrm{RCD} 1$ & & & & $0,233^{* *}$ & $0,401^{* *}$ & $0,169^{*}$ & $0,353^{* *}$ & $0,300^{* *}$ & 0,116 & 0,009 & $0,162^{*}$ & 0,112 \\
\hline HL & & & & & $0,376^{* *}$ & $0,565^{* *}$ & $0,355^{* *}$ & $0,305^{* *}$ & $0,183^{* *}$ & $0,193^{* *}$ & $-0,054$ & $0,183^{* *}$ \\
\hline $\mathrm{CN}$ & & & & & & $0,388^{* *}$ & $0,411^{* *}$ & $0,254^{* *}$ & 0,095 & 0,076 & $-0,141^{*}$ & $0,148^{*}$ \\
\hline CL & & & & & & & $0,431^{* *}$ & $0,265^{* *}$ & $0,240^{* *}$ & $0,215^{* *}$ & $-0,174^{*}$ & $0,245^{* *}$ \\
\hline $\mathrm{CW}$ & & & & & & & & $0,233^{* *}$ & $0,248^{* *}$ & 0,117 & $-0,069$ & $0,200^{* *}$ \\
\hline $\mathrm{RCD} 2$ & & & & & & & & & $0,672^{* *}$ & $0,421^{* *}$ & 0,024 & $0,640^{* *}$ \\
\hline EL & & & & & & & & & & $0,611^{* *}$ & $-0,03$ & $0,692^{* *}$ \\
\hline NL & & & & & & & & & & & $-0,033$ & $0,436^{* *}$ \\
\hline NW & & & & & & & & & & & & $-0,061$ \\
\hline
\end{tabular}

Heritability $\mathrm{H} 2$ estimates were shown in Table 5. Since the greater value of $\mathrm{H} 2$ means greater heritability, it was found that CL, CW, EL, NW were strongly inherited characteristics with $\mathrm{H} 2$ values of $0.63,0.71$, 0.63 and 0.73 respectively. Genetic variances among population were much lower than those within the populations (Figure 3).
The ratio of genetic variation among the populations was $3.48 \%$ for GP, $3.4 \%$ for SR, 0.83 for SR/GP, 0.8 for RCD1, 4.56 for HL, 13.03 for CN, 9.92 for CL, 13.65 for CW, 4.98 for RCD2, 5.99 for EL, 3.01 for NL, 15.35 for NW and 1.46 for BN. Genetic variations among the populations were ranged from 0.8 (RCD) to $15.35 \%(\mathrm{NW})$ across all populations. 
Table 5. Estimated heritability values as to the morphological traits

\begin{tabular}{llll}
\hline Among & Mean squares & \\
Trait & $\begin{array}{c}\text { Within } \\
\text { populations }\end{array}$ & 571,55 & $\mathrm{H}^{2}$ \\
\hline GP & 956,18 & 581,19 & 0,40 \\
SR & 965,39 & 232,77 & 0,40 \\
GP/SR & 261,20 & 0,03 & 0,11 \\
RCD1 & 0,03 & 15,26 & 0,10 \\
HL & 24,41 & 17,62 & 0,37 \\
CL & 47,32 & 0,02 & 0,63 \\
CW & 0,05 & 0,08 & 0,71 \\
RCD2 & 0,18 & 198,86 & 0,57 \\
EL & 540,76 & 10,42 & 0,63 \\
NL & 17,02 & 0,01 & 0,39 \\
NW & 0,05 & 2,39 & 0,73 \\
BN & 4,79 & & 0,50 \\
\hline
\end{tabular}

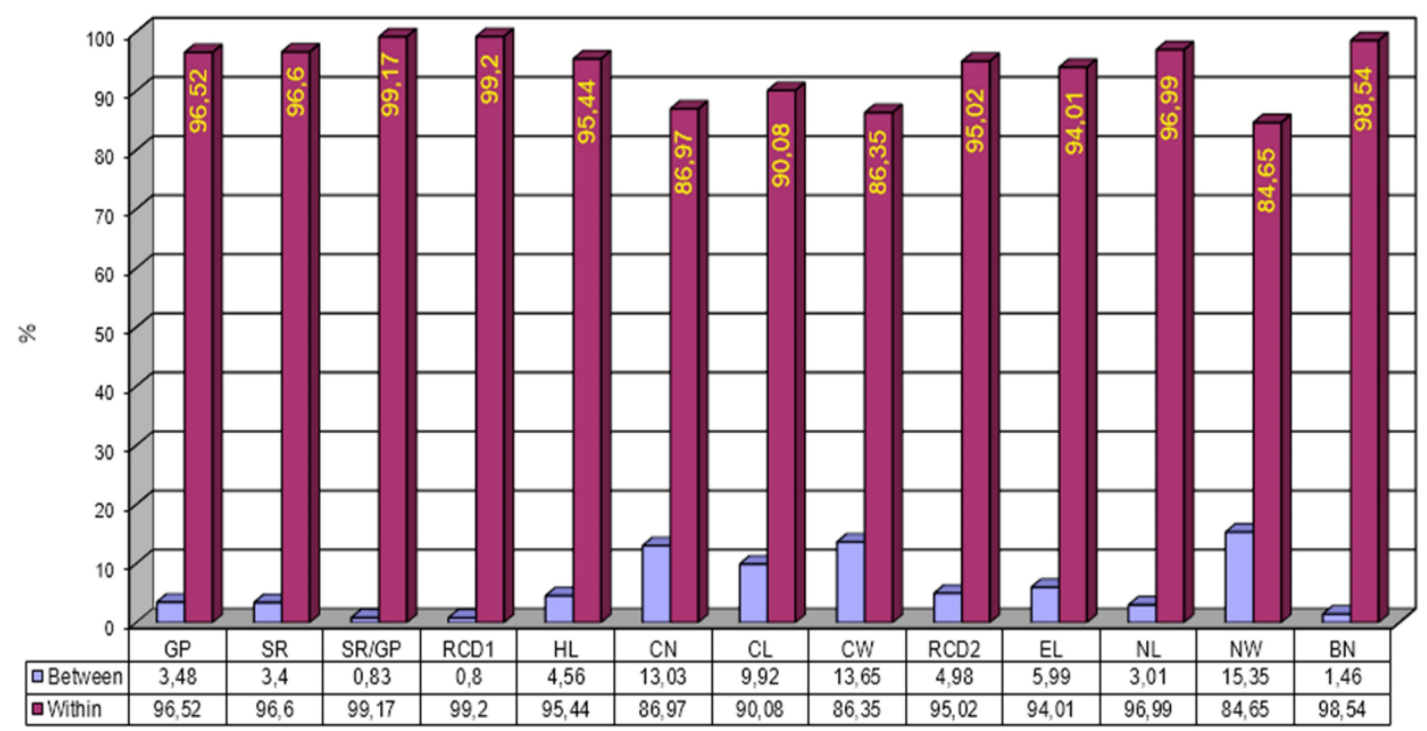

Figure 3. Genetic variances among populations and within the populations.

\section{Discussion and Conclusion}

Morphological and seedling characteristics (Iş̧1k \& Kaya, 1995; Sivacıŏlu, 2010; Sevik, 2012; Sevik et al., 2012; Topacoglu, 2013) as well as isoenzymes analysis (Turna, 2003; Bilgen \& Kaya, 2007) and DNA markers (Clark et al., 2000) have been commonly utilized to define genetic variations. Genetic variation of several species including Pinus ponderosa (Linhart et al. 1981), Pinus sylvestris (Quencez \& Bastien 2001; Şevik et al. (2010) and Pinus oocarpa (Romero et al. 2006) have been studied. In this study, a significant genetic variation within and among the populations of Calabrian pine seed stands were determined following the observation of 13 morphological traits, and 14 seed stands at varying elevations ranging from 60 to $925 \mathrm{~m}$. Genetic variances among the populations were much lower than those within populations.

Işık (1986) monitored the altitudinal variation in Calabrian pine in 3 different zones (coastal, central and inland populations), and found that a clinal genetic variation in seedling traits across the elevation gradient in the Toros mountains, 
southern Turkey. Işık (1986) further suggested that the variation depended on the distance to the Mediterranean Coast. Our findings may substantiate this suggestion because we usually observed lowest values across all traits for the seed stands at or higher than $650 \mathrm{~m}$ of elevation. Calabrian pine usullay establishes pure stands at low altitudes, mostly from sea level to $600 \mathrm{~m}$. It is possible that populations at or lower than $650 \mathrm{~m}$ in altitudes presented higher shoot flushes which may further influence seedling height growth. After monitoring 13-years old Calabrian pine seedlings, Yildırım (1992) stated that $50 \%$ of the height growth was because of two or more shoot flushes.

Heritability (H2) estimates shown in Table 5 suggested that CL, CW, EL, and NW were the strongly inherited characteristics. Similarly, Iş1k (1986) pointed out that terminal growth $(\mathrm{H} 2=0.72)$ of Calabrian pine showed strong inheritance, and overall, narrow sense heritabilities were determined. Seedling morphology as an early stage indicator can be used for estimation of later growth because it shows stability of early developmental stages. The high variation within the populations and heritability values indicated the opportunities of high selection intensity in the breeding programs for Calabrian pine in Turkey. However, it should be noted that maternal effects should be considered in breeding programs because they may influence the heritability and fitness in natural populations (Roach \& Wullf, 1987; Zas et al., 2013). Phenotypic maternal effects can be either genetic or environmental effects that may also have influence on seed size and germination (Roach \& Wullf, 1987). Zas et al. (2013) stated that maternal environmental effect can affect seedling weight, and this can be transmitted through several generations. Although it was not measured in this study, it is possible that seed size can have influence on early seedling growth measurements. In comparison to smaller-seeded species, seedlings from large seeds may be more vigorous, and less dependent on soil nutrient availability (Milberg et al., 1998; Waters \& Reich, 2000; Zas et al., 2013).

Populations 2 and 14 were the closest populations in terms of genetic distance while Populations 8 and 9 were the closest regarding the geographical proximities. Morphological distances can play an important role for evaluating the variation among the populations. The different traits that have different units are pooled while calculating the morphological distances.

Although there has been an increasing interest in the afforestation activities within the natural distribution area of Calabrian pine in Turkey, there has been still problems with finding proper seed sources. Due to the significant genetic variation within and among the populations of Calabrian pine, seed selection from these populations may be more advantageous than selection conducted at the family level alone (Iş̧1k \& Kaya, 1997). In addition, Halgren \& Helms (1992) stated that populations with multiple shoot flushes can be selected because it is likely that populations with multiple shoot flushes would flush in the following years (Işık \& Kaya, 1997). The data presented in this paper would give useful information on the genetic variation of Calabrian pine at varying sites and elevations. Findings may be used to increase the success of afforestation activities in Turkey.

This study provides data concerning the genetic diversity of Calabrian pine based on some morphological traits. The examined 14 populations have a high level of genetic variation. In this study, genetic diversity was not associated with geographical proximity among the populations. In addition, the findings showed higher variation within population (within families) than among populations. Thus, for forestry practices including selection of seed sources, determination of seed transfer zones, and genetic resource conservation programs, family level of variation must be considered. It is important to note that this study was based on only 14 of seed stands of Calabrian pine. Regarding the high levels of variation found among and within populations, this kind of studies should be replicated for the all seed stands located on the same seed transfer zone in Turkey. This study may help future studies regarding the pattern of genetic variation in adaptive seedling traits. 


\section{References}

Anonymous. 2014. Forest atlas. Publications of General Directorate of Forestry. 116 p. Available at: https://www.ogm.gov.tr/ekutuphane/Yayi nlar/Orman\%20Atlasi.pdf.

Anon (2013). Activity Plan of Industrial Plantations (2013-2023), Ministry of Forest and Water Affairs, General Directorate of Forestry, 100 p. Ankara (in Turkish).

Anon (2016). Seed Stands, Research Directorate of the Forest Tree Seeds and Tree Breeding, http://ortohum.ogm.gov.tr/Sayfalar/IslahTesisleri.aspx\#

Bilgen B, Kaya BN (2007). Allozyme Variations in Six Natural Populations of Scots Pine (Pinus sylvestris L.) in Turkey. Biologia, 62, 697-703.

Boydak M., Dirik H., Çalıkoğlu M (2006). Biology and Silviculture of Turkish Red Pine (Pinus brutia Ten.). OGEM Foundation Publication. Lazer Offset Press, 253 pp., Ankara (in Turkish)

Boydak, M., (2004). Silvicultural characteristics and natural regeneration of Pinus brutia Ten. a review. Plant Ecology 171: 153-163.

Clark, C.M., Wentworth, T.R., O'Malley, D.M. (2000). Genetic Discontinuity Revealed by Chloroplast Microsatellites in Eastern North American Abies (Pinaceae). American Journal of Botany 87:774-782.

Erkan, N. (1996). Simulation of stand development in calabrian pine (Pinus brutia Ten.). Southeastern Anatolia Forestry Research Directorate Publication, Technical bulletin. No: 1, pp: 147. Elazı ğ (in Turkish).

Glowacki, W., Stephan, B.R. (1994). Genetic variation of Pinus sylvestris from Spain in relation to other European populations, Silvae Genetica 43(1):7-14.

Gülcü, S., Çelik, S. (2009). Genetic variation in Pinus brutia Ten. seed stands and seed orchards for growth, stem form and crown characteristics. African Journal of Biotechnology 8(18):4387-4394.

Gülcü, S., Üçler, A.Ö. (2008). Genetic Variation of Anatolian Turkish pine (Pinus brutia Ten. subsp. pallasiana
(Lamb.) Holmboe) in the Lakes District of Turkey, Silvae Genetica 57:1-5.

Gülcür, M., Akkgül, E., Koç, M. (1993). Importance of $P$. brutia in watershed afforestations. Proceedings of the International Symposium on Pinus Brutia Ten. Marmaris, Turkey, October 18-23, 1993 Ministry of Forestry, pp.403-410 (in Turkish).

IBM SPSS Statistics (2009). International Business Machines Corp. New York, USA.

Iş1k, K. (1986). Altitudinal Variation in Pinus brutia Ten. Seed and Seedling Characteristics. Silvae Genetica 35(23):58-67.

Işık, F., Kaya, Z. (1995). The Pattern of Genetic Variation in Pinus brutia Ten. Populations Sampled Along a South To North Transect In Taurus Mountains. Journal of Western Mediterranean Forestry Research Institute Number 1, Antalya.pp:20-54 (in Turkish).

Işık, F., Kaya, Z. (1997). The Pattern of Genetic Variation in shoot growth of Pinus brutia Ten. Populations Sampled from the Toros Mountains in Turkey. Silvae Genetica 46:73-81.

Küçük, Ö., Bilgili, E., Sağlam, B. (2008). Estimating crown fuel loading for calabrian pine and Anatolian black pine. International Journal of Wildland Fire 17:147-154.

Kurt, Y., Bilgen, B.B., Kaya, N., Işı1k, K. (2011). Genetic Comparison of Pinus brutia Ten. Populations from Different Elevations by RAPD Markers. Notulae Botanicae Horti Agrobotanici ClujNapoca 39(2):299-304.

Linhart, Y.B., Mitton, B.J., Sturgeon, K.B., Davis, M.L. (1981). Genetic variation in space and time in a population of ponderosa pine, Heredity 46:407-426.

Matziris, D. (1984). Genetic variation in morphological and anatomical needle characteristics in the black pine of Peloponnesos. Silvae Genetica 33:164169.

Milberg, P., Pérez-Fernandez, M.A., Lamont, B.B. (1998). Seedling growth response to added nutrients depends on seed size in 
three woody genera. Journal of Ecology 86: 624-632.

Millar, Constance, I. (1999). Genetic Diversity. Maintaining Biodiversity in Forest Ecosystems. Edited by Malcolm L. Hunter JR. 460-494.

Muller-Starck, G., Baradat, Ph., Bergmann, F. (1992). Genetic variation within European tree species. New Forest 6:2347.

Neyişçi, T. (1987). The natural distribution of calabrian pine. In: Calabrian pine manual series. Forestry research institute publications. No 52, pp. 17-22 (in Turkish).

Quencez, C., Bastien, C. (2001). Genetic variation within and between populations of Pinus sylvestris L. (Scots pine) for susceptibility to Melampsora pinitorqua Rostr. (pine twist rust), Heredity 86:3644.

Panetsos, K.P. (1981). Monograph of Pinus halepensis and Pinus brutia. Annales Forestales 9: 39-77.

Rao, C.R. (1971). Minimum variance quadratic unbiased estimation of variance components. Journal of Multivariate Analysis 1:445-456.

Roach, D.A., Wulff, R.D. (1987). Maternal Effects in Plants. Annual Review of Ecology and Systematics 18: 209-235.

Romero, C.S., Guzma'n-Reyna, R.R., Rehfeldt, G.E. (2006). Altitudinal genetic variation among Pinus oocarpa populations in Michoaca'n, Mexico Implications for seed zoning, conservation, tree breeding and global warming. Forest Ecology and Management 229:340-350.

SAS Institute Inc. (1987). Cary, NC, USA.

Sivacioğlu, A., Ayan, S. (2010). Variation in cone and seed characteristics in a clonal seed orchard of Anatolian black pine (Pinus nigra Arnold subsp. pallasiana (Lamb.) Holmboe), Journal of Environmental Biology 31:119-123.

Sivacioğlu, A. (2010). Genetic variation in seed and cone characteristics in a clonal seed orchard of Scots pine (Pinus sylvestris L.) grown in KastamonuTurkey, Romanian Biotechnological Letters 15(6):5695-5701.
Sivacioğlu, A., Ayan, S., Çelik, D.A. (2009). Clonal variation in growth, flowering and cone production in a seed orchard of Scots pine (Pinus sylvestris L.) in Turkey", African Journal of Biotechnology 8(17):4084-4093.

Swallow, W.H., Monahan, J.F. (1984). Monte Carlo comparison of ANOVA, MIVQUE, REML, and ML estimators of variance components. Technometrics 26:47-57.

Şevik, H. (2012). Variation in seedling morphology of Turkish fir (Abies nordmanniana subsp. bornmulleriana Mattf), African Journal of Biotechnology 11(23): 6389-6395.

Şevik, H., Ayan, S., Turna, İ., Yahyaoğlu, Z. (2010). Genetic diversity among populations in Scotch pine (Pinus sylvestris L.) seed stands of Western Black Sea Region in Turkey, African Journal of Biotechnology 9(43):72667272.

Şevik, H., Yahyaoğlu, Z., Turna, İ. (2012). Determination of Genetic Variation Between Populations of Abies nordmanniana subsp. bornmulleriana Mattf According to some Seed Characteristics, Genetic Diversity in Plants, InTech 12:231-248.

Topacoglu, O. (2013). Genetic diversity among populations in Black Pine (Pinus nigra Arnold. subsp. pallasiana (Lamb.) Holmboe) seed stands in Turkey. Bulgarian Journal of Agricultural Science, 19(6), 1459-1464.

Turna, İ. (2003). Variation of Morphological and Electrophoretic Characters of 11 Populations of Scots Pine in Turkey, Israel Journal of Plant Sciences 51(3):223-230.

Waters, M.B., Reich, P.B. (2000). Seed size, nitrogen supply, and growth rate affect seedling survival in deep shade. Ecology 81: 1887-1901.

Yıldırım, T. (1992). Genetic variation in shoot growth patterns in Pinus brutia Ten. M. Sci. Thesis, Middle East Technical University, Department of Biological Sciences, Ankara. 53 p ([in Turkish).

Yücedağ, C., Gailing, O. (2013). Genetic variation and differentiation in Juniperus 
excels M. Bieb. populations in Turkey, Trees 27:547-554.

Zas, R., Cenda'n, C., Sampedro, L. (2013). Mediation of seed provisioning in the transmission of environmental maternal effects in Pinus pinaster. Heredity 111: 248-255. 